\title{
Pharmaceutical study of Shilajatu processed in different media
}

\author{
Research article
}

\section{Richa Pathak $^{1^{*}, \text { Singh }_{\text {RS }}{ }^{2} \text {, Neeraj Kumar }}{ }^{1}$}

1. Department of Rasa Shastra, Faculty of Ayurveda IMS, BHU, Varanasi.

2. Department of Chemical Engineering and Technology, Indian Institute of technology (BHU), Varanasi

\begin{abstract}
Shilajatu is considered one of the wonderful medicines of Ayurveda. Neither a plant nor animal substance, it is a mineral pitch that oozes from the rocks of Himalayas, as they become warm in the summer month. Shilajatu is a blackish brown exudation of variable consistency found in the serene surroundings of Himalayas. It is composed of humus and organic plant material that has been compressed by layers of rock mixed with microbial metabolites. Crude shilajatu was collected from Prem nagar Ashram, Haridwar and pure shilajatu was extracted from it by two methods i.e. water and gomutra. Water extracted shilajatu was subjected to shodhan by triphala kwatha and guduchi kwatha then it is used for experimental study. Gomutra extracted shilajatu was used in experimental study without any processing. Yield of Shiajatu using Gomutra was 38.5\% and shilajatu using water was $37.7 \%$ shilajatu. After shodhan with triphala kwatha gain in weight of shilajatu was $51 \%$ and in guduchi kwatha weight was increased by $38 \%$.
\end{abstract}

Key words: Shilajatu, Gomutra, guduchi kwatha, triphala kwatha

\section{Introduction}

Shilajatu is considered one of the wonder medicines of Ayurveda. Neither a plant nor animal substance, it is a mineral pitch that oozes from the rocks of the Himalayas, as they become warm in the summer months. It is said to carry the healing power of these great mountains [1]. Shilajatu is an important drug of the ancient Hindu material medica and is to this day used extensively by the physicians for a variety of diseases. Shilajatu is a blackish brown exudation found in the serene surroundings of Himalayas. It is

*Corresponding Author:

\section{Richa Pathak,}

Department of Rasa Shastra,

Faculty of Ayurveda,

IMS, BHU,

Varanasi.

E,mail -docricha@yahoo.com also found in most of the sedimentary rocks especially in Afghanistan, Bhutan, China, Nepal, Pakistan, USSR, Tibet as well in Norway, where they are gathered from steep rock faces at attitudes between 1000 and $5000 \mathrm{~m}$. Shilajatu is composed of humus and organic plant material that has been compressed by layers of rock mixed with microbial metabolite. Traditional uses primarily focus on diabetes and diseases of the urinary tract, but also include edema, tumors, wasting, epilepsy and even insanity [2]. Modern indications extend to all system oh the human body with a significant number of additions in the reproductive and nervous system. Shilajatu cannot be used as such: they need proper processing to develop medicinal qualities. Pharmaceutical study includes mainly identification, collection of crude drugs \& its various pharmaceutical processing like shodhan, 
bhavana etc. for enhancing the therapeutic effect of a prepared drug.

In this era of globalization it is the need of time to explore the scientific basis of medicaments of Ayurveda. To provide the scientific data about the preparation of the medicaments with having this goal in mind, this work was carried out to trace each \& every aspect of four preparations made out of crude Shilajatu, extraction of Shilajatu by water as well as gomutra, then water extracted Shilajatu was subjected to shodhan with triphala [3] and guduchi kwatha [4].

\section{Pharmaceutical study}

Pharmaceutical study includes mainly collection of crude drugs \& pharmaceutical processing like shodhan etc, by this blemish are separated from the substances by various processing with specific drugs. Shodhan is a process of purification \& detoxification by which physical, chemical blemishes \& toxic materials are eliminated and substances are subjected for further processing.

\section{Procurement and identification Drugs}

Crude Shilajatu samples were procured from Hansa Ayurvedic Pharmacy Premnagar Ashram, Haridwar (Uttrakhand). It was identified by experts of Department of Rasa Shastra, Faculty of Ayurveda, IMS, Banaras Hindu University. Crude Shilajatu was blackish brown in colour, intense odour of cow urine and sticky in nature.

\section{Process of Extraction}

Extraction of Shilajatu was done by two method i.e. Water extraction and Gomutra extraction.

\section{Water extraction [5]}

$2.0 \mathrm{~kg}$ crude Shilajatu was dissolved in four times i.e. eight litres of hot tap water and kept in steel vessel-1, it was mixed by stirring and kept for $24 \mathrm{hr}$. for settling down of water insoluble material, after $24 \mathrm{hrs}$ the mixture had supernatant liquid covered with thin layer and muddy sediment. The supernatant liquid was filtered with the help of cotton cloth into another steel vessel -2 . Again 2 litres of hot water was added to vessel -1 and both the vessels were kept for $24 \mathrm{hrs}$, next day contents of vessel -2 was decanted into third steel vessel-3 and of vessel -1 into vessel -2 . All the above processes were repeated until the formation of thin layer on the surface of liquid in final steel vessel disappeared and clean solution formed.

\section{Gomutra Extraction [6]}

$1.0 \mathrm{~kg}$ crude Shilajatu was made it to small pieces mixed with 2 litres of gomutra \& kept undisturbed for $24 \mathrm{hrs}$. After 24 hours supernatant gomutra covered with thin layer and muddy sediment. The supernatant gomutra was filtered with the help of cotton cloth \& sedimented residual matter was again mixed with gomutra \& kept undisturbed. This process was continued till whole of the gomutra become clear of all the impurities. This solution was now kept in hot air oven at $70^{\circ} \mathrm{C}$ up to dryness. Dried sample were stored in a steel jar for further study.

\section{Shodhan of Shilajatu}

Processing of water extracted Shilajatu was done by two methods. In first method Shilajatu was levigated with triphala kwatha for seven times. For each time of levigation triphala kwatha was prepared by $100 \mathrm{gm}$ of triphala powder with $800 \mathrm{ml}$ of water reducing to $100 \mathrm{ml}$. In second method Shilajatu was levigated with gudhuchi kwatha [7] for seven times. For each time of levigation guduchi kwatha was prepared by $100 \mathrm{gm}$ of guduchi with $800 \mathrm{ml}$ of water reducing to $100 \mathrm{ml}$. Details are summarised in table-2. 
Table 1: Showing observation of extraction using water and gomutra

\begin{tabular}{|l|l|l|l|l|l|l|}
\hline S.N. & $\begin{array}{l}\text { Media } \\
\text { used }\end{array}$ & $\begin{array}{l}\mathbf{P}^{\mathrm{H}} \\
\text { of } \\
\text { media }\end{array}$ & $\begin{array}{l}\text { Appearance of } \\
\text { solution }\end{array}$ & $\begin{array}{l}\text { Smell of } \\
\text { extracted } \\
\text { Shilajatu }\end{array}$ & $\begin{array}{l}\text { Colour of } \\
\text { extracted } \\
\text { Shilajatu }\end{array}$ & \% yeld \\
\hline 1 & Water & 7 & $\begin{array}{l}\text { Not easily miscible } \\
\text { with hot water } \\
\text { Colour of solution: } \\
\text { reddish brown colour }\end{array}$ & $\begin{array}{l}\text { intense } \\
\text { cow urine } \\
\text { odour }\end{array}$ & $\begin{array}{l}\text { Blackish } \\
\text { brown }\end{array}$ & 37.7 \\
\hline 2 & Gomutra & 8 & $\begin{array}{l}\text { Thin layer of foam } \\
\text { formed over the } \\
\text { gomutra. } \\
\text { Colour of solution: } \\
\text { dark brown. }\end{array}$ & $\begin{array}{l}\text { Pungent } \\
\text { smell of } \\
\text { gomutra. }\end{array}$ & $\begin{array}{l}\text { Bright } \\
\text { brown }\end{array}$ & 38.5 \\
\hline
\end{tabular}

Table 2: Showing observation of shodhan of Shilajatu with triphala kwatha and guduchi kwatha as a media.

\begin{tabular}{|l|l|l|l|l|l|l|}
\hline S.N & $\begin{array}{l}\text { Quantity of } \\
\text { purified } \\
\text { Shilajatu } \\
\text { (gm) }\end{array}$ & $\begin{array}{l}\text { Media } \\
\text { used }\end{array}$ & $\begin{array}{l}\text { Consumed } \\
\text { amount } \\
\text { media (m) }\end{array}$ & $\begin{array}{l}\text { Duration } \\
\text { (days) }\end{array}$ & $\begin{array}{l}\text { Quantity of } \\
\text { processed } \\
\text { Shilajatu } \\
\text { (gm) }\end{array}$ & $\begin{array}{l}\text { Percentage } \\
\text { gain/loss }\end{array}$ \\
\hline 1 & 100 & $\begin{array}{l}\text { Triphala } \\
\text { kwatha }\end{array}$ & 700 & 20 & 151 & 51 gain \\
\hline 2 & 100 & $\begin{array}{l}\text { Guduchi } \\
\text { kwatha }\end{array}$ & 700 & 14 & 138 & 38 gain \\
\hline
\end{tabular}

\section{Result}

$37.7 \%$ \& $38.5 \%$ yield of Shilajatu was procured by water and gomutra extraction technique respectively. Weight of Shilajatu was increased $51 \%$ \& $38 \%$ by shodhan with triphala kwatha and guduchi kwatha.

\section{Discussion}

Crude Shilajatu is generally not easily available in local market it has to be procured from high altitude rocks or can be obtained from Pharmaceutical industries. Due to this various type of unwanted materials was present in Shilajatu. Keeping this fact in mindextraction of Shilajatu was done using water and gomutra as a media. Gomutra methods of Shilajatu extraction have more percentage yield than water method of Shilajatu extraction. Cow urine contains nitrogen, magnesium, silicon, iron, sodium and calcium etc. due to presence of these element percentage yields of Shilajatu with gomutra may be slightly higher than water extracted[8]. Drugs of both mineral and metal origin should be subjected to shodhan process before they are to be used as such internally or in the preparation of any other compound form of drugs. Researches has shown that natural form of Shilajatu is often contaminated by varying amounts of impurities such as mycotoxins, heavy metal ions, polymeric quinones, reactive free radicals, etc. Mycotoxins are produced by mold or fungi and can cause illness or death in man. Free radicals can be harmful to cells and are believed to be a causative factor in aging. Polymeric quinones are an oxidation product of quinic acid which is found in some plants. Hence, it is necessary to purify the Shilajatu before it is consumed [9]. Shodhan of Shilajatu with triphala $k w a t h a$ by levigation method gives more yield than guduchi kwatha shodhit. It was 
observed that triphala kwatha has more percentage of solid content than guduchi kwatha. So \% gain is observed more in triphala kwatha shodhit Shilajatu as compared to guduchi kwatha shodhit Shilajatu.

\section{Conclusion}

Shilajatu extracted by gomutra provides more percentage yield than Shilajatu extracted using water as a media. Further when water extracted Shilajatu was subjected to shodhan by triphala kwatha and guduchi kwatha then we found that weight of shodhit Shilajatu using triphala kwatha as a media was more as compared to guduchi kwatha.

\section{References}

1. Frawley, David and Lad, Vasant. The Yoga of Herbs. 2 edition. Lotus Press. Twin Lakes, WI, 2001. 250p.

2. Dangar R. Shilajit: overview. Digitally signed LMC Pharmacy dated 09.02.2011.1-18p.
3. Shastri HS. Ashtang Hridaya with Hindi translation.reprint ed. Chaukhambha Surbhartiya Prakashana, Varanasi 2010. 933p.

4. Shastri HS. Ashtang Hridaya with Hindi translation.reprint ed Chaukhambha Surbhartiya Prakashana, Varanasi 2010. 933p.

5. Laxmipati S. Yogratnakar with Vidyotini Hindi commentary, $2^{\text {nd }}$ edition, Chaukhambha Visvabarati 1973 , Shilajatu prakarana 1-5, 162p.

6. Sharma Sadanand, Rasa Tarangani $.11^{\text {th }}$ edition. Motilal Banarasi Das press.2009. 586p.

7. Gupta VM et al. Pharmaceutical study and Pharmacological of Shilajatu, IMS, BHU Dec 2010. 52-70p.

8. N.K.Jain et al. Efficacy of cow urine therapy on various cancer patients in Mandsaur Distrit, India- A Survey, International Journal of Green Pharmacy, Jan-Mar 2010. 29-35p.

9. Suraj P. et.al. Shilajit: A Review Phytotherapy Research Phytother. Res. 21. 2007. 401-405p. 